$\begin{array}{lcrllll}\text { M. P. } & \begin{array}{c}\text { Subst. } \\ \text { g. }\end{array} & \text { Nc.c. } & \text { P.m.m. } & \text { T } & \text { N.found } & \text { Calculated for } \\ \text { 1. } 122^{\circ} & 0.1183 & 22.7 & 759.2 & 25^{\circ} & 21.43 \% & 21.76\left(\mathrm{C}_{0} \mathrm{H}_{11} \mathrm{~N}_{3} \mathrm{O}_{2}\right) \\ \text { 2. } 88-90 & 0.1075 & 19.9 & 755.7 & 25 & 20.57 & 20.30\left(\mathrm{C}_{10} \mathrm{H}_{13} \mathrm{~N}_{3} \mathrm{O}_{2}\right) \\ \text { 3. } 126 & 0.0526 & 9.7 & 759.0 & 25 & 20.59 & 20.30\left(\mathrm{C}_{10} \mathrm{HI}_{13} \mathrm{~N}_{3} \mathrm{O}_{2}\right) \\ \text { 4. } 110 & 0.0846 & 14.4 & 758.7 & 23 & 19.20 & 19.01\left(\mathrm{C}_{11} \mathrm{H}_{15} \mathrm{~N}_{3} \mathrm{O}_{2}\right) \\ \text { 5. } 149 & 0.1008 & 18.8 & 764.8 & 18 & 21.68 & 21.76\left(\mathrm{C}_{9} \mathrm{H}_{11} \mathrm{~N}_{3} \mathrm{O}_{2}\right)\end{array}$

III. Acetic acid formation from ethyl-alcohol by saké yeast.

Medium : ethyl-alcohol 240c.c. (alc. $96.2 \%$ ald. $0.002074 \%$ ) water 2820 c.c. yeast mud $57 \mathrm{~g}$.

Aldehyde and total acid after 66 days at $25^{\circ} \mathrm{C}$ was each $0.02038 \mathrm{~g}$. and $0.048 \mathrm{~g}$. per 100c.c. of culture.

Silver content of Ag-salt prepared from the distillate :-

$\begin{array}{cccc}\text { Subst. } & \mathrm{AgCl} & \mathrm{Ag} . \text { found } & \mathrm{Ag} \text {. calculated for } \mathrm{C}_{2} \mathrm{H}_{3} \mathrm{O}_{2} \mathrm{Ag} . \\ 0.2062 \mathrm{~g} . & 0.1748 \mathrm{~g} . & 63.78 \% & 64.64 \%\end{array}$

IV. Oxiclation of propyl alcohol by Bac. xylinum at $20^{\circ} \mathrm{C}$.

Medium: a. propyl alcohol 30c.c., $\left(\mathrm{NH}_{4}\right)_{2} \mathrm{HPO}_{\ddagger} \quad 0.5 \mathrm{~g} . \quad \mathrm{KCl} \quad 0.1 \mathrm{~g}$ water 970 c.c.

b. $\quad \mathrm{a}+\mathrm{CaSO}_{3} 20 \mathrm{~g}$.

Microbes: Bacteria-mud developed in $1 \mathrm{~L}$. of koji extract.

(a.) Total acid after 35 days $0.2738 \mathrm{~g}$. per. 100c.c.

Silver content of $\mathrm{Ag}$-salt prepared from the destillate.

$\begin{array}{llcc}\text { Subst. } & \mathrm{AgCl} & \mathrm{Ag} \text { found } & \mathrm{Ag} \text { calculated for } \mathrm{C}_{3} \mathrm{H}_{5} \mathrm{O}_{2} \mathrm{Ag} \\ 0.3282 \mathrm{~g} . & 0.2578 \mathrm{~g} & 59.11 \% & 56.62 \%\end{array}$

(b.) Aldehyde after 32 days $0.07948 \mathrm{~g}$. per 100c.c.

Character of $\mathrm{p}$-nitrophenylhydrazone prepared.

M.P. Subst. N N.found N.Culc. for $\mathrm{C}_{0} \mathrm{H}_{11} \mathrm{~N}_{3} \mathrm{O}_{2}$

$1210 \quad 0.1068 \mathrm{~g} \quad 20.9$ c.e. $\quad\left(25^{\circ} \mathrm{C} 756.2 \mathrm{~mm}\right) \quad 2176 \% \quad 21.76 \%$.

\title{
ON THE PRODUCTION OF ACETOIN AND 2.3- BUTYLENGLYCOL BY MICROBES AND THEIR DISTRIBUTION IN FERMENTATION PRODUCTS.
}

By Masakazu Yamada and Kanroku Kurono.

(Received Apr. 22nd., 1927.)

It has often been reported that the reducing substance in vinegars is 
acetyl methyl-carbinol. ${ }^{(1)}$

On the other hand, the production of acetoin and its related compound, 2.3- butylenglycol by microbes, especially by several bacteria has repeatedly been described under the name of butylen glycol-fermentation in the culture media containing glucose, fructose, mannit, glycerine or Ca-lactate as a carbon source. ${ }^{(2)}$ As to the production of both compounds by yeast Kluyver, Donker and Visser't Hooft confirmed that the glycol was formed everytime while acetoin rarely in the sugar solution. ${ }^{(3)}$

The mechanism of their production is not yet accurately known except the explanation put forward by C. Neuberg and their associates. They say that acetaldehyde which is formed in nascent state as an intermediate product in the fermentation of the sugar undergoes an acyloin like conjugation with acetaldehyde, when the latter is added to the fermented liquid, by aid of carboligase and the acetoin thus formed, is reduced into butylenglycol phytochemically. ${ }^{(4)}$ But Elion obtained acetoin from the dilute ethylalcohol or acetaldehyde solution by the yeast. ${ }^{(5)}$

Jately $\mathrm{T}$. Taira reported on the distribution of the butylenglycol in Japanese fermentation products, without referring to acetoin. Therefore the production of these two compounds by microbes and their distribution in main fermentation products have been newly tested.

The results are as follows :-

1. Bacteria produced a considerable quantity of both compounds.

2. Yeasts and a fungus produced a little of both except Pichia and Chalara.

3. The butylenglycol existed in saké(fresh and old), putrid saké, shōyu, tamari-shoyu, wine, beer and vinegar, that is to say, in almost all kinds of fermentation products; it may be regarded therefore as an ordinary component of all fermentation products.

4. Acetoïn was found in putrid saké, shôyu, tamari-shōyu and vinegar.

5. Acetoïn may be taken as a component which distinguishes the imitated vinegar from the fermented one, for it was not detected in the former.

6. Also the detection of acetoin may be used to distinguish saké and putrid saké while it must be careful that a minute quantity was found in

(1) C. A. Browne: $\quad$ J. Pastureau :

Farnsteiner :

(2) A. Jlarden. u. G. S. Walpole: Proc. Roy. Soc. B. 77, 399, 1906; Harden u. Norris: Ibid. 84, 492. Ruot: C. r. Acad. 157, 247-99, 1913; M. Lemoigne : Ibid. 155, 792-95: 157, 653-55; 177, 652-54; C-r. Soc. Biol. 82, 984, 83; 336-8; 88,467.

(3) Bioch. Z. 161, 361, 1925.

(4) C. Neuberg u. E. Rein forth: Bioch. Z, 143, 553, 1923.

(5) Elion: Ibid, 40-44, 
"moto" - culture of saké yeast in saké brewing and koji extract culture fermented by saké yeast.

7. There was no production of both compounds in the dilute alcohol solution cultivated with saké yeast or acetic acid bacteria contrary to Elion's experiment.

\section{Experimental}

Medium : for yeast and fingus; 50c.c. of koji extract $\left(10^{\circ} \mathrm{Balling}\right)$ for bacteria; 50c.c. of neutralized koji extract $\left(10^{\circ} \mathrm{B}\right)$ to which $1.5 \mathrm{~g}$. of $\mathrm{CaCO}_{3}$ is added.

Microbes: Each 1 platinum ear was inoculated.

Detection: By Lemoigne's method developed by Kluyver and his associates. (3) (Formation of Characteristic red crystal of Nickel dimethylglyoxim.)

Production or existence is shown in the following table.

0 was not tested.

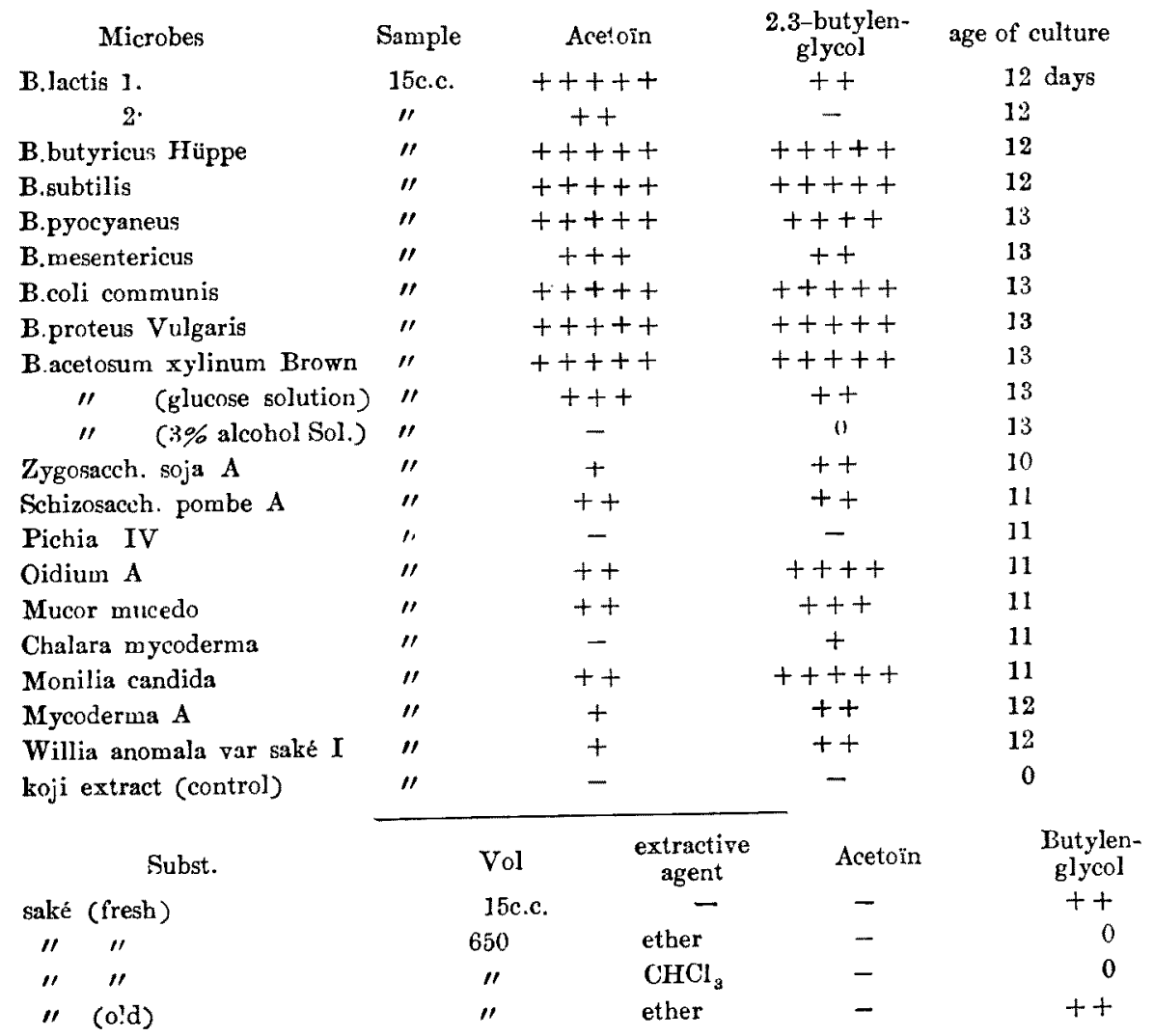


[Vol. 3,

\begin{tabular}{|c|c|c|c|c|}
\hline Shōyu & 150 & $\mathrm{CHCl}_{\mathrm{a}}$ & ++ & ++++ \\
\hline Tamari-shōyu & 100 & $\mathrm{CHOI}_{3}$ & $+t$ & ++ \\
\hline wine & 15 & - & 0 & ++ \\
\hline beer (Yebisu) & 500 & $\mathrm{CHCl}_{3}$ & - & + \\
\hline$" \prime \prime$ & 15 & - & - & - \\
\hline vinegar & 15 & - & ++ & $+t+$ \\
\hline $\begin{array}{l}\text { moto } \\
\prime \prime\end{array}$ & $\mathrm{J} 5$ & - & - & + \\
\hline $\begin{array}{l}\prime \prime \\
\text { putrid saké }\end{array}$ & 900 & $\mathrm{CHCl}_{3}$ & + & 0 \\
\hline $\begin{array}{l}\text { putrid saké } \\
\text { Koji ex. fermented by saké yeast }\end{array}$ & 15 & - & + & ++ \\
\hline $\begin{array}{l}\text { Koji ex. fermented by saké yeast } \\
\text { after } 6 \text { days }\end{array}$ & 15 & - & - & \pm \\
\hline n. $" \prime$ & 500 & $\mathrm{CHCl}_{3}$ & ++ & + \\
\hline Koji extract(not fermented) & 2000 & ether & - & - \\
\hline $\begin{array}{l}5 \% \text { alcohol solution } \\
\text { with saké yeast }\end{array}$ & 1400 & ether & - & - \\
\hline
\end{tabular}

